\title{
PENGEMBANGAN INSTRUMEN PENILAIAN HASIL BELAJAR RANAH KOGNITIF MODEL 4D PADA MATERI SEPAK BOLA BERDASARKAN KURIKULUM 2013
}

\author{
I Dewa Gede Putra Wirayasa ${ }^{1}$, I Putu Darmayasa², I Made Satyawan³ \\ 1,2,3Universitas Pendidikan Ganesha \\ Email: dewawirayasa71@gmail.com¹, putu.darmayasa@undiksha.ac.id², \\ made.satyawan@undiksha.ac.id ${ }^{3}$
}

\begin{abstract}
Abstrak
Penelitian ini bertujuan untuk mengembangkan instrumen penilaian hasil belajar ranah kognitif, guna mengetahui validitas isi dan butir, reliabilitas, daya beda, serta tingkat kesukaran dari kelayakan instrumen yang dikembangkan. Jenis penelitian yang digunakan yaitu pengembangan (developmental research). Pada penelitian ini menggunakan model penelitian 4D. Subyek penelitian ini adalah instrumen penilaian hasil belajar ranah kognitif materi sepak bola berupa kisi-kisi dan tes hasil belajar PJOK. Data dikumpulkan menggunakan metode tes. Data yang diperoleh akan dianalisis validitas, reliabilitas, daya beda, serta tingkat kesukaran masing-masing instrumen. Nilai rata-rata dari pengujian analisis data menunjukkan data yang diuji memiliki validitas yang sangat tingi. Hasil pengujian reliabilitas menunjukkan tingkat reliabilitas yang tinggi. Hasil pengujian daya beda, menunjukkan hasil yang bervariasi tiap kelas yang diuji. Tingkat kesukaran menunjukkan hasil pengujian data yang bervariasi pula dalam tingkat kelasnya. Dari hasil pengujian data yang dilaksanakan pada seluruh kelas X di SMA Negeri 1 Amlapura dapat dinyatakan bahwa pengembangan instrumen hasil belajar ranah kognitif materi sepak bola layak dikembangkan dan digunakan dalam penilaian hasil belajar kepada peserta didik.
\end{abstract}

Kata kunci : instrumen, hasil, belajar, ranah kognitif, model 4D

\begin{abstract}
This study aims to develop an instrument for assessing learning outcomes in the cognitive domain, in order to determine the content and item validity, reliability, differentiation, and difficulty level of the appropriateness of the developed instrument. The type of research used is development (developmental research). In this study using a $4 D$ research model. The subject of this study was an instrument for assessing the cognitive realm of learning outcomes in soccer material in the form of a grid and a test of learning outcomes in PJOK. Data were collected using the test method. The data obtained will be analyzed for validity, reliability, difference power, and the level of difficulty of each instrument. The average value of the data analysis test shows the data being tested has a very high validity. Reliability test results show a high level of reliability. The results of the different power test showed that the results varied for each class being tested. The level of difficulty shows the results of data testing that also vary in the grade level. From the results of data testing carried out in all class $X$ at SMA Negeri 1 Amlapura it can be stated that the development of learning outcomes instruments in the cognitive domain of football material is feasible to be developed and used in the assessment of learning outcomes for students.
\end{abstract}

Key word: instruments, learning outcomes, cognitive domains, 4D models 


\section{PENDAHULUAN}

Sumber Daya Manusia (SDM) merupakan salah satu hal yang sangat penting dikembangkan dalam menghadapi persaingan di era globalisasi ini. Mengembangkan sumber daya manusida dapat dilakukan dengan beberapa faktor. Salah satunya yaitu dengan pendidikan. Melalui sektor pendidikan, manusia diharapkan mampu mewujudkan segala potensi yang ada didalam dirinya. Pendidikan sudah didapatkan sejak kita terlahir di dunia ini. Keluarga adalah pendidikan yang utama dan pertama yang didapatkan oleh anak, sebelum akhirnya nanti anak mengenal dunia pendidikan secara formal. Perkembangan zaman yang semakin maju, ditambah perkembangan globalisasi yang tidak terkendali mengharuskan membentuk pendidikan yang berkualitas.

Kualitas pendidikan suatu negara mencerminkan kemajuan negara tersebut. Peningkatan kualitas pendidikan pada suatu negara harus dilaksanakan guna menciptakan sumber daya manusia yang memiliki daya saing yang tinggi dan berkualitas. Kualitas pendidikan dapat dicapai melalui proses pembelajaran yang berkualitas pula.

Guna meningkatkan kualitas dan mutu pendidikan di Indonesia, menteri pendidikan telah berulang kali melakukan perubahan serta pembaharuan mengenai kurikulum yang digunakan dalam dunia pendidikan guna menghasilkan lulusan yang lebih berkompeten dari lembaga formal yaitu sekolah salah satunya aalah jenjang SMA. Pembelajaran di jenjang SMA, banyak mengalami perubahan, perkembangan serta pemabaharuan dari jenjang-jenjang sebelumnya. Pada jenjang SD peserta didik telah banyak diajarkan tentang pembelajaran yang sifatnya mendasar, kemudian pada jenjang SMP pembelajaran mulai menjadi bervariasi, dan pada jejang SMA pembelajaran yang didapatkan siswa menjadi semakin kompleks. Salah satu pembelajaran yang didapatkan oleh siswa mulai dari jenjang SD - SMA adalah PJOK.

Menurut (Sunaryo, 2017), pendidikan jasmani merupakan bagian integral dari pendidikan keseluruhan yang bertujuan meningkatkan individu secara organik, neuromouskuler, intelektual dan emosional melalui jasmani. Tujuan pendidikan jasmani adalah untuk mengembangkan kebugaran fisik, emosional dan sosial melalui kegiatan fisik. Sedangkan menurut (Efriwaldi, 2020), pendidikan jasmani dan pendidikan olahraga merupakan dua macam pendidikan yang saling berhubungan sehingga pada saat ini nama dari pendidikan tersebut telah digabung menjadi pendidikan jasmani, olahraga dan kesehatan atau yang lebih dikenal dengan istilah PJOK.

Pembelajaran PJOK tidak selalu melibatkan fisik dari peserta didik, tetapi memerlukan kemampuan intelektual (kognitif) dari peserta didik, dikarenakan dalam pemelajaran PJOK tidak hanya berfokus pada praktik siswa dilapangan, melainkan juga pada kemampuan siswa didalam kelas.

Hasil observasi serta wawancara pada bulan Oktober tahun 2020 di SMA Negeri 1 Amlapura pada guru pengampu mata pelajaran PJOK khususnya di kelas $\mathrm{X}$, mendapatkan data bahwa hasil belajar PJOK khusunya dalam ranah kognitif atau pengetahuan siswa masih tergolong rendah. Untuk melengkapi hasil wawancara dan observasi yang telah dilakukan, maka dilanjutkan dengan studi dokumen nilai UTS PJOK siswa kelas $X$ di SMA Negeri 1 Amlapura. Berdasarkan dari hasil studi dokumen nilai ulangan tengah semester PJOK menunjukkan masih banyak siswa yang mendapatkan nilai di bawah Kriteria Ketuntasan Minimal (KKM). $\mathrm{Hal}$ ini membuktikan bahwa masih rendahnya hasil belajar dan pemahaman siswa terhadap pelajaran PJOK khususnya materi Sepak Bola.

Adapun beberapa hal yang menyebabkan rendahnya hasil belajar PJOK berdasarkan observasi di kelas $X$ SMA Negeri 1 Amlapura diantaranya, guru masih belum mampu memaksimalkan penerapan satu model pembelajaran inovatif, guru masih berpusat pada kemampuan fisik siswa, guru kurang didalam menjelaskan materi PJOK didalam kelas serta guru sering mengalami kesulitan untuk evaluasi yang diunakan tidak dapat mengukur dengan baik dan 
tidak sesuai dengan yang harus diukur, sehingga data yang didapatkan tidak akurat dan salah.

Dengan adanya permasalah tersebut, penulis menawarkan solusi yaiu degan mengembangkan instrumen penilaian ranah kognitif yang dapat digunakan oleh guru untuk menilai hasil belajar PJOK peserta didik. Adapun solusi ini dipilih dikarenakan mengingat jika instrumen tersebut terus digunakan, maka akan memberikan penilaian yang bersifat bias. Penelitian pengembangan ini, tentu saja memiliki perbedaan dengan penelitian pengembangan yang dilakukan oleh (Aji \& Winarno, 2016); (Ardyanto, Winarno, \& Adi, 2016); dan (Juniarta \& Winarno, 2016). Perbedaanya terletak pada subjek peneliian yang digunakan yaitu siswa SMA kelas $X$ serta materi yang digunakan pada penelitan ini hanya berfokus pada materi sepak bola.

Saat menentukan instrumen penilaian hasil belajar siswa khususnya dalam ranah kogntif, guru dituntut agar dapat menentukan isntrumen penilaian hasil belajar yang tepat serta dapat menilai sejauh mana pengembangan hasil belajar siswa dalam proses pembelajaran PJOK. Instrumen penilaian hasil belajar yang dikembangkan adalah bentuk tes pilihan ganda (objektif).

Hasil belajar merupakan hasil akhir yang dicapai siswa setelah mengalami proses belajar PJOK yang tampak dalam perbuatan yang dapat diamati dan diukur. Menurut (Susanto, 2013a), hasil belajar didefinisikan sebagai perubahanperubahan yang tersjadi pada diri peserta didik, baik yang menyangkut aspek kognitif, aspek afektif, dan aspek psikomotor sebagai hasil dari kegiatan belajar. Nawawi (dalam Susanto, 2013b), mendefinisikan hasil belajar adalah tingkat keberhasilan peserta didik dalam mempelajar materi pembelajaran di sekolah yang dinyatakan dalam skor yang diperoleh dari hasil tes mengenal sejumlah materi pembelajaran tertentu. Berdasarkan definisi para ahli diatas, dapat disimpulkan bahwa hasil belajar merupakan suatu perubahan yang terjadi karena adanya kegiatan yang disebut denga belajar dan mengajar dan waktu tertentu, hasil belajar juga dijadikan sebagai sebuah ukuran dalam menilai pemahaman siswa dalam kegiatan pembelajaran.

\section{METODE PENELITIAN}

Penelitian ini menggunakan jenis Research and Development. Dalam penelitian ini model pengembangan yang digunakan adalah model pengembangan $4 \mathrm{D}$, yang meliputi define, design, develop, dan disseminate (Riscaputantri \& Wening, 2018). Tahap disseminate dalam penelitian ini dilaksanakan secara daring (dalam jaringan) dengan menggunakan bantuan google formulir.

Pada peneltian ini pelaksanaan model 4D terdiri atas fase: 1) tahap define merupakan tahapan untuk menetapkan dan mendefinisikan syarat-syarat pembelajaran. Pada tahap ini terdiri atas analisis kebuuhan, analisis karakterisik peserta didik, serta analisis tugas yang didapatkan oleh peserta didik. 2) tahap design atau perencanaan merupakan tahap yang bertujuan untuk merancang perangkat pembelajaran. Pada tahap ini menekankan mengenai tujuan merencanakan sebuah kerangka awal instruen penilaian hasil belajar PJOK untuk siswa SMA kelas X. 3) Tahap develop merupakan pengembangan merupakan tahap yang bertujuan untuk menghasilkan suatu produk dari pengembangan yang dilakukan dengan bentuk akhir perangkat pembelajaran setelah melalui revisi berdasarkan masukan dari para pakar ahli/ praktisi dan data hasil uji coba. Pada tahap ini memiliki tujuan untuk menghasilkan seuah prosuk dalam bentuk pengembangan instrumen. Instrumen yang dihasilkan pada tahap ini akan melewati proses bimbingan, pengujian ahli serta perbaikan. Penilaian oleh ahli dilakukan dengan cara menguji serta menganalisis dengan menggunakan pedoman penilaian pada validitas isi dengan menggunakan validitas butir. Pada lembar penilaian 
validitas, ahli memberikan penilaian untuk tiap butir soal yang ada, serta memberikan masukan jika terdapat hal yang perlu diperbaiki dari soal tersebut guna menyempurnakan produk yang dihasilkan dan uji pengembangan produk (developmental testing). Uji coba dilakukan pada seluruh kelas $X$ di SMA Negeri 1 Amlapura yang terdiri dari 7 kelas serta dengan jumlah siswa sebanyak 249 orang peserta didik. pada tahap terakhir yaitu 4) tahap disseminate merupakan suatu tahap akhir dari kegiatan pengembangan, pada tahap ini dilakukan secara daring (dalam jaringan) dengan bantuan google formulir, hal tersebut terjadi dikarenakan ketidak mungkinan pelaksanaan pengujian instrumen pengembangan hasil belajar secara langsung, mengingat situasi yang belum kondusif.

Instrumen peilaian hasil belar PJOK ranah kognitif peserta didik menggunakan kisi-kisi, serta lembar tes objektif siswa. Arikunto (dalam (Aji \& Winarno, 2016) menyatakan bahwa ters merupakan kumpulan masalah dalam bentuk pertanyaan yang diserahkan kepada siswa guna mengukur pemahaman serta keahian peserta didik. Sedangkan (Amalia \& Susilaningsih, 2014) menyatakan bahwa isntrumen penilaian hasil belajar merupakan bagian dari suatu proses penilaian didalam kegiatan pembelajaran.

Instrumen hasil belajar PJOK ranah kognitif materi sepak bola disusun berdasarkan KD sepak bola yang hanya muncul pada semester I, selanjutnya dikembangkan menjadi 7 indikator dan menghasilkan 30 butir soal objektif. Pada setiap butir soal terdapat 5 butir jawaban yang dapat menjadi alternatif pilian siswa.

Pada penelitian ini menggunakan teknik analsis data berupa analisis validitas, reabilitas, daya beda serta tingkat kesukaran soal. Untuk teknik analisis validitas terbagi kedalam validitas isi dan validitas butir. Validitas isi instrumen hasil belajar PJOK ranah kogntif materi sepak bola telah diuji oleh dua orang ahli yang terdiri atas 2 dosen undiksha dilingkungan Fakultas Olahraga. Skor hasil validitas yang diberikan oleh ahli dimasukkan kedalam tabel tabulasi silang yang disajikan pada tabel 1.

Tabel 1 Tabulasi Silang

\begin{tabular}{|c|c|c|c|}
\hline \multicolumn{4}{|c|}{ Penilai 1} \\
\hline & & $\begin{array}{c}\text { Kurang } \\
\text { Relevan } \\
\text { (skor 1-2) }\end{array}$ & $\begin{array}{c}\text { Sangat } \\
\text { Relevan } \\
\text { (skor 3-4) }\end{array}$ \\
\hline \multirow{2}{*}{ 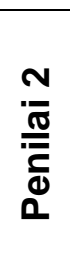 } & $\begin{array}{c}\text { Kurang } \\
\text { Relevan } \\
\text { (skor 1-2) }\end{array}$ & (A) & (B) \\
\hline & $\begin{array}{c}\text { Sangat } \\
\text { Relevan } \\
\text { (skor 3-4) }\end{array}$ & (C) & (D) \\
\hline
\end{tabular}

Hasil validitas dari kedua ahli yang sudah dimasukkan kedalam tabel tabulasi silang yang kemudian dianalisis menggunakan rumus Gregory didapatkan hasil sebagai berikut.

$V=\frac{D}{A+B+C+D}$

Keterangan:

$\mathrm{V}=$ Validitas Isi
$\mathrm{A}=$ Kedua ahli tidak setuju

$\mathrm{B}=$ Ahli 2 tidak setuju, ahli 1 setuju

C = Ahlli 2 setuju, ahli 1 tidaka setuju

$\mathrm{D}=$ Kedua ahli setuju

Hasil perhitungan yang didaoat, selanjutnya dicocokkan dengan kriteria koefisien validitas isi. Berikut merupakan penjelasan mengenai kriteria validitas isi yang diuraikan pada Tabel 2. 
Tabel 2 Kriteria Validitas Isi

\begin{tabular}{cl}
\hline $\begin{array}{c}\text { Koefisien Validitas } \\
\text { Isi }\end{array}$ & \multicolumn{1}{c}{ Kriteria } \\
$0,80-100$ & validitas sangat tinggi \\
$0,60-0,79$ & validitas tinggi \\
$0,40-0,59$ & validitas sedang \\
$0,20-0,39$ & validitas rendah \\
$0,00-0,19$ & validitas sangat rendah \\
\hline
\end{tabular}

Validitas butir digunakan untuk mengetahui banyak instrument soal yang valid dan gugur. Validitas butir instrumen tes hasil belajar PJOK ranah kognitif materi sepak bola dihitung menggunakan korelasi point biserial. Adapaun penyajian rumus korelasi point biserial (Candiasa, 2011).

$r_{p b i}=\frac{M_{p}-M_{t}}{S_{t}} \sqrt{\frac{p}{q}}$

Keterangan:

$r_{p b i}=$ Teknik korelasi point biserial

$M_{p}=$ Rerata skor subjek yang menjawab benar

$\mathrm{M}_{\mathrm{t}}=$ rerata skor total

$\mathrm{S}_{\mathrm{t}}=$ standar deviasi dari skor total

$p=$ proporsi peserta didik yang menjawab benar butir yang dicari validitasnya

$\mathrm{q}=$ proporsi peserta didik yang menjawab salah butir yang dicari validitasnya $(q=1-$ p)

Setelah melakukan uji validitas, dilanjutkan dengan yji reliabilitas, uji daya beda, serta uji tingkat kesukaran butir soal.
(Agung, 2011) mendefinisikan untuk menguji reliabilitas instrument yang bersifat politomo maka digunakan rumus Kuder Richardson 20 (KR-20).

$r_{11}=\left(\frac{k}{k-1}\right)\left(\frac{S_{t}^{2} \Sigma p q}{S_{t}^{2}}\right)$

Keterangan:

$\mathrm{R}_{1.1}=$ koefisien reabilitas perangkat tes

$\mathrm{k}=$ banyak butir tes

$\mathrm{S}_{\mathrm{t}} \quad=$ standar deviasi skor total

$\mathrm{p}=$ proporsi peserta didik yang menjawab benar tiap-tiap butir

$\mathrm{q}=$ proporsi peserta didik yang menjawab salah tiap-tiap butir

Untuk mennetukan butir item yang baik atau buruk, maka perlu dibandingkan antara nilai $r$ hitung dengan nilai t table (taraf signifikansi 5\%). Butir item dikatakan handal jika memiliki nilai $r$ hitung $>t$ table. Namun jika sebaliknya, maka butir item dikatakan tidak baik (reliabel). Adapun kriteria tingkar reabilitas dijelaskan pada Tabel 3 berikut.

Tabel 3 Kriteria Reliabilitas Instrumen

\begin{tabular}{cc}
\hline Skor & Kriteria \\
\hline $0,00<r \leq 0,20$ & Sangat rendah \\
$0,20<r \leq 0,40$ & Rendah \\
$0,40<r \leq 0,60$ & Sedang \\
$0,60<r \leq 0,80$ & Tinggi \\
$0,80<r \leq 1,00$ & Sangat tinggi \\
\hline
\end{tabular}

HASIL dan PEMBAHASAN

Berdasarkan penelitian yang telah dilaksanakan, adapun hasil pengembangan berupa instrument hasil belajar PJOK materi sepak bola untuk siswa kelas $\mathrm{X}$. Adapun model penelitian pengembangan yang peneliti gunakan adalah model penelitian pengembangan 4D, yang meliputi define, design, develop dan disseminate Instrumen yang digunakan untuk mengukur nilai hasil belajar PJOK siswa SMA Kelas $\mathrm{X}$ adalah 
dalam bentuk tes objektif pilihan ganda. Instrumen hasil belajar PJOK materi sepak bola disusun berdasarkan KD yang terdapat pada pelajaran PJOK SMA kelas $X$ yang dikembangkan menjadi 7 buah indicator.

Instrument hasil belajar PJOK disusun berdasarkan KD mata pelajaran PJOK di SMA kelas $X$, yang selanjutnya dikembangkan menjadi 7 indikator soal dan menghasilkan butir soal pilihan ganda sebanyak 30 butir. Pada setiap butir soal yang ada, terdapat 5 alternatif jawaban yang bisa dipilih oleh peserta didik. Instrument penilaian hasil belajar PJOK menghasilkan kisi-kisi dan lembar tes objektif pilihan ganda yang berjumlah 30 butir soal, yang selanjutnya dilaksanakan uji validitas isi dengan dua orang judges sebagai penilai uji kelayakan soal yang akan digunakan. Berdasarkan hasil analisis data menunjuukan sebanyak 30 butir soal dinyatakan valid dan relevan untuk digunakan pada tahap selanjutnya yaitu tahap uji coba. Setelah tahap uji coba dilaksanakan, kemudian peneliti melaksanakan analisis pada tiap-tiap butir soal yang dijawab oleh siswa dengan mengghitung validitas butir soal, reabilitas butir soal, daya beda soal, serta tingkat kesukaran soal yang kemudian dirataratakan. Berikut merupakan hasil uji validitas, rebilitas, daya beda, dan tingkat kesukaran dari ke 7 kelas yang menjadi subjek uji coba di SMA Negeri 1 Amlapura. Data hasil analisis disajikan pada table 4.

Tabel 4 Hasil Analisis Data Uji Coba Berdasarkan Rata-rata 7 kelas X di SMA Negeri 1

Amlapura

\begin{tabular}{lll}
\hline Analisis/ Uji & Nilai Rerata & Kriteria \\
\hline Validitas Isi & 91,6 & Sangat tinggi \\
Reliabilitas & 0,89 & Sangat tinggi \\
Tingkat Kesukaran & 20,24 & Sukar \\
Daya Beda & 11,05 & Kurang Baik \\
\hline
\end{tabular}

Berdasarkan table di atas, adapun hasil validitas isi instrument hasil belajar PJOK dengan rumus Gregory diperoleh hasil rat-rata dari ketujuh kelas adalah 91 , 6 dengan kriteria sangat tinggi. Selanjutnya pada hasil analisis uji reliabilitas dari ke tujuh kelas didapatkan rata-rata sebesar 0,89 dan termasuk kedalam kriteria sangat tinggi. Data hasil uji coba tingkat kesukaran didapatkan hasil yang menunjukkan ratarata pada tujuh kelas tersebut adalah 20,24 yang mana termasuk kedalam kriteria sukar, dan yang terakhir hasil uji daya beda soal dari ketujuh kelas berdasarkan ratarata dari masing-masing jawaban siswa menunjukkan hasil yang kurang baik dengan nilai sebesar 11,05.

Berdasarkan hasil data rerata di atas, dapat diberikan kesimpulan bahwa instrument hasil belajar PJOK materi sepak bola memiliki validitas, reliabilitas, tingkat kesukaran dan daya beda soal yang baik. Menurut (Hayati \& Lailatussaadah, 2016), data dikatakan bersifat akurat jika nilai validitas serta reliabilitas instrumennya juga semakin tinggi.

Hasil penelitian ini didukun oleh penelitian (Aji \& Winarno, 2016) yang menunjukkan instrument hasil belajar PJOK sebanyak 100 butir soal yang digunakan sangat valid dengan hasil reabilitas yang diperoleh sebanyak 0,80 , kemudian untuk daya beda menunjukkan hasil $5 \%$ data bersifat negative, $10 \%$ data masuk kekatagori jelek dan 33\% data masuk kekategori baik. Sehingga dapat disimpulkan bahwa instrument penilaian dengan 100 butir soal telah memenuhi standar kriteri tes yang baik. Adapun penelitilian lain dari (Juniarta \& Winarno, 2016) yang menunjukkan hasil validitas dan reabilitas, instrument hasil belajar PJOK adalah seperti berikut. Hasil uji coba pada kelompok kecil dengan jumlah soal sebanyak119 soal hanya 2 soal yang dinyatakan tidak valid, kemudian hasil uji 
reliabilitas soal menunjukkan angka sebesar 0,94 dengan klasifikasi tinggi. Pada kelompok ini untuk tingkat kesukaran soal dan daya beda soal memiliki variasi. Terdapat 3 soal dengan kategori mudah, 67 soal termasuk kategori sedang serta 48 soal termasuk kategori sukar. Sedangkan pada kelompok besar yang diuji dengan soal sebanayak 119 butir soal didapatkan hasil bahnya seluruh soal dikatakan valid dan hasil analisis reliabilitas soal menunjukkan nilai 0,92 dengan klasifikasi tinggi. Kemudian pada hasil analisis tingkat kesukaran soal dan daya beda pada kelompok ini didapatkan hasil bahwa sebanyak 117 butir soal termasuk kedalam kategori sedang dan 2 butir soal dengan kategori sukar, sehingga dapat disimpulkan bahwa data yang digunakan sudah bersifat valid sehingga instrument tersebut layak untuk digunakan sebagai intsrumen penelitian.

Instrumen penilaian hasil belajar PJOK ranah kognitif materi sepak bola layak dikembangkan sebagai instrument penilaian. Hal ini karena instrument penilaian merupakan sesuatu yang wajib dimilliki guru dalam proses pembelajaran sebagai alat bantu yang dapat digunakan untuk memeroleh sebuah informasi guna mengetahui tingkat kemampuan peserta didik secara objektif. Sepaham dengan pemikiran Arikunto (dalam Hardiani, 2017), menyatakan bahwa instrument merupakan sebuah alat yang dapat digunakan untuk memudahkan suatu tugas untuk mencapai tujuan secara efektif. Sedangkan (Amalia \& Susilaningsih, 2014) menyatakan bahwa instrument penilaian merupakan bagian dari suatu proses penilaian didalam kegiatan pembelajaran.

\section{SIMPULAN}

Berdasarkan pemaparan hasil dan pemabahasan di atas, dapat diberikan kesimpulan sebagai berikut. 1) Pengembangan instrument penilaian hasil belajar PJOK ranah Kognitif materi sepak bola kela $X$ yang berjumlah 30 butir soal objektif adapun hasil analisis data yang diperoleh dari tujuh kelas yang terdiri atas 249 orang peserta didik didapatkan hasil sebagai berikut. Hasil analisis validitas isi menunjukkan rata-rata akhir adalah sebesar 91,6 dengan klasifikasi validitas sangat tinggi. Kemudian hasil analisis reliabilitas dengan merata-ratakan hasil dari ke tujuh kelas tersebut diperoleh hasil yang menunjjukan sebesar 0,89 dengan klasifikasi sangat tinggi. Hasil analisis tingkat kesukaran soal berdasarkan jawaban siswa sebanyak 249 orang didapatkan rata-rata hasil yang menunjukkan hasil sebesar 20,24 dengan klasifikasi sukar. Hasil analisis daya beda soal berdasarkan jawaban siswa sebanyak 249 orang didapatkan hasil rata-rata adalah sebesar 11,05 dengan klasifikasi daya pembeda yang kurang baik.

Saran yang dapat peneliti sampaikan meliputi: 1) guru PJOK selaku pendidik dan orang tua siswa di sekolah diharapkan tidak hanya berfokus kepada kegiatan motorik kasar peserta didik atau hanya berfokus kepada kemampuan fisik (praktik dilapang) siswa, tetapi guru seharusnya mampu mengembangkan hasil belajar siswa khususnya pada ranah kognitif siswa yang semakin lama semakin menurun. 2) Guru PJOK diharapkan mampu menggunakan instrument yang layak dan memenuhi syarat sebagai alat ukur standar penialaian yang baik khususnya pada penilaian hasil belajar siswa pada ranah kognitifnya. 3) Kepala sekolah hendaknya memfasilitasi guru guna meningkatkan keterampilannya didalam mengembangkan instrument penilaian khususnya pada penilaian hasil belajar dalam aspek kognitif, agar guru mampu menghasilkan alat evaluasi penilaian pembelajaran yang memiliki kualitas sehingga mampu menghasilkan daya saing serta mutu pendidikan yang lebih baik di sekolah tersebut. 4) Bagi peneliti lain agar dapat menggunakan penelitian ini sebagai acuan dalam mengembangkan instrument penilaian hasil belajar PJOK ranah kognitif dengan fokus materi pada sepak bola sebagai acuan didalam 
mengembangkan isntrumen penilaian dengan topik atau mata pelajaran lainnya. Peneliti lain juga dapat melanjutkan penelitian ini dengan mengembangkan materi pelajara, kelas serta jenjang yang berbeda.

\section{DAFTAR PUSTAKA}

Agung, A. G. A. (2016). Statistika Dasar untuk Pendidikan (CV BUDI UT). Yogyakarta.

Aji, B. S., \& Winarno, M. E. (2016). Pengembangan Instrumen Penilaian Pengetahuan Mata Pelajaran Pendidikan Jasmani Olahraga dan Kesehatan (PJOK) Kelas VIII Semester Gasal. Jurnal Pendidikan, 1(7), 1449-1463.

Amalia, N. F., \& Susilaningsih, E. (2014). Pengembangan instrumen penilaian keterampilan berpikir kritis siswa SMA pada materi asam basa. Jurnal Inovasi Pendidikan Kimia, 8(2), 1380-1389.

Ardyanto, E., Winarno, M., \& Adi, S. (2016). Pengembangan Instrumen Pengetahuan Mata Pelajaran Pendidikan Jasmani Olahraga Kesehatan (Pjok) Untuk Siswa Kelas Xii Sekolah Menengah Atas. Jurnal Pendidikan - Teori, Penelitian, Dan Pengembangan, 1(10), 1897-1903. https://doi.org/10.17977/jp.v1i10.689 4

Candiasa, I. M. (2010). Pengujian Instrumen Penelitian Disertasi Aplikasi Iteman dan Bigsteps. Singaraja: Unit Penerbit Universitas Pendidikan Ganesha.

Hardiani, I. N. (2017). Pengembangan instrumen penilaian sikap sosial pembelajaran IPS kelas IV SD. EJournal Mitra Pendidikan, 1(6), 615628.

https://doi.org/10.1017/CBO9781107 415324.004

Hayati, S., \& Lailatussaadah, L. (2016). Validitas Dan Reliabilitas Instrumen Pengetahuan Pembelajaran Aktif, Kreatif Dan Menyenangkan (Pakem) Menggunakan Model Rasch. Jurnal Ilmiah Didaktika, 16(2), 169. https://doi.org/10.22373/jid.v16i2.59

$$
3
$$

Juniarta, A. T., \& Winarno, M. E. (2016). Pengembangan Instrumen Penilaian Pengetahuan Mata Pelajaran Pendidikan Jasmani Olahraga dan. (April 2015), 267-283.

Riscaputantri, A., \& Wening, S. (2018). Pengembangan instrumen penilaian afektif siswa kelas IV sekolah dasar di Kabupaten Klaten. Jurnal Penelitian Dan Evaluasi Pendidikan, 22(2), 231-242. https://doi.org/10.21831/pep.v22i2.1 6885

Sunaryo, M. (2017). Implementasi Model Pembelajaran Active Learning Tipe Pengadilan Majelis Hakim Dalam Pembelajaran PJOK Materi Narkoba dan Pelecehan Seksual Pada Siswa Kelas VI SDN Tanggulangin I. Pendidikan Dan Pembelajaran Dasar, $\quad 9(2), \quad 81$. https://doi.org/10.18860/jt.v9i2.4790

Susanto, A. (2013a). Teori Belajar \& Pembelajaran di Sekolah Dasar (1st ed.). Jakarta: PRENADAMEDIA GROUP.

Susanto, A. (2013b). Teori Belajar dan Pembelajaran di Sekolah Dasar (1st ed.; Jefry, ed.). https://doi.org/978602-7985-11-7 